\title{
RATOON STUNTING DISEASE OF SUGARCANE IN SRI LANKA
}

\author{
D. L. JAYARATNE* AND S. WIDANAPATHIRANA ${ }^{+}$ \\ Department of Microbiology, Faculty of Science, University of Kelaniya, \\ Kelaniya, Sri Lanka.
}

(Date of receipt : 10 March 1987)

(Date of acceptance : 21. August 1987)

\begin{abstract}
Causative bacterium of Ratoon Stunting Disease (R.S.D.) of sugarcane was isolated and characterized in this study. The study of the life cycle of this bacterium, carried out using a micromanipulator under the phase contrast microscopic field, indicated the characteristic cell division of the bacterium. The bacterium has the ability to survive on an inneret glass surface without any nutrient up to about 19 days. Results also indicated that the hot water treatment currently. employed to prepare R.S.D. free seed cane is not effective and that this organism is resistant to moderate concentrations of phenol and lysol. The disease surveys indicated that the R.S.D. incidence in hot water treated primary nursery was found to be $25 \%$ and that of secondary nursery was $33 \%$. The yield reduction in sugarcane plant crop due to R.S.D. infection was found to be about $10 \%$.
\end{abstract}

\section{Introduction}

The Ratoon Stunting Disease (R.S.D.) of Sugarcane has been recorded since 1961 in Sri Lanka. Hutchinson ${ }^{5}$ reported that the infection was present in every stalk which he observed during his visit in the island.

The disease causes significant yield losses, especially when cane is growing under water stress conditions. The yield reduction is more severe in ratoon crops than in plant crops.

The electron microscopic studies ${ }^{3,10}$ showed that a coryneform bacterium is always associated with the diseased sugarcane plants. The bacterium was isolated and its pathogenicity tested for the first time in 1980..$^{1}$ Davis $e t$ al ${ }^{2}$ proposed a new genus Clavibacter for some phytopathogenic coryneform bacteria. Accordingly causative bacterium of R.S.D. was classified as Clavibacter xyli sub sp. xyli sp nov. sub sp. nov. ${ }^{2}$

The disease diagnosis of R.S.D. is often confused as the external and internal symptoms are not specific. Therefore electron microscopic method $^{3}$ or phase contrast microscopic method 9 are used for reliable diagnosis.

\footnotetext{
* Sugarcane Research Institute, Kantale, Sri Lanka.
}

+ Department of Microbiology, Faculty of Science, University of Kelaniya, Kelaniya, Sri Lanka. 
The Hot Water Treatment at $50^{\circ} \mathrm{C}$ for 2 or 3 hours is used to eliminate the infection in seedcane setts. Sterilization of cane knives prior to harvesting and chopping seed cane, prevents further spread of the disease.

The present investigation was carried out on the following lines to obtain more information on R.S.D. in Sri Lanka.

(a) R.S.D. diagnosis and survey.

(b) The effect of the disease on cane yield and juice quality.

(c) Isolation, identification and life cycle studies of the causative bacterium.

(d) Pathogenicity of the bacterium.

(e) Efficiency of the Heat Treatment.

(f) Viability of the bacterium on implements used in sugarcane cultivation.

(g) Sensitivity to the disinfectants.

\section{Experimental}

\subsection{Ratoon Stunting Disease Survey}

The disease survey was carried out in hot water treated primary and secondary nurseries at Sugarcane Research Station, Kantale. The bioassay technique developed by Davis $e$ t al., ${ }^{1}$ was used to diagnose this disease. In this method a "three budded sett" selected from a single stalk was split open longitudinally using a clean sharp knife and examined for vascular bundle discolourations at the nodes just below the leaf scar, with continuous slicing towards the same direction. 1

The survey area for each site was about $10 \%$ of total extent (i.e. sample field). The percentage infestation was determined from randomly selected stools which represented $1 \%$ of the sample field.

2.2 The effect of the R.S.D. bacterium on cane yield, juice quality and fibre content of sugarcane

A replicated yield trial was carried out in Reddish Brown Earth at Sugarcane Research Station, Kantale using the commercial Sugarcane variety Co 775. The disease free seed material were selected from the hot water treated primary nursery. The seed materials were tested and selected by both bioassay technique ${ }^{1}$ and phase contrast microscopy technique. ${ }^{9}$

Half of the seed materials were treated with sugareane juice which was extracted from R.S.D. plants. The treated and control (healthy) seed 
materials were planted in 30 feet long furrows $\mathrm{x} 4$ rows in each block. Thirty three budded setts were planted in each row. The statistical design was randomized block design with fourteen replicates.

Pol \%, Brix, Fibre content were determined according to the methods used in sugarcane Research Institute. ${ }^{12}$

\subsection{Microscopic observations of Diseased plant tissues and vascular sap.}

Microtome sections of the diseased plant stems and leaves were mounted on Formaline Acetic Acid Alcohol (FAA) solution and observed under the light microscope to assess the physical damage of vascular elements caused by R.S.D. bacterium. ${ }^{7}$

Vascular sap was extracted by suction pressure method and examined under phase contrast microscope (Olympus - BH2) for R.S.D. causative bacterium. ${ }^{9}$

\subsection{Isolation of R.S.D. bacterium}

A small piece of stem tissue excised from the nodal region of disease sugarcane plant was surface sterilized with $0.1 \%$ Mercuric chloride solution and rinsed in sterilized distilled water. The sap was expressed from the tissue with the aid of sterilized forceps into (a) sterile distilled water (b) sterile $0.01 \mathrm{M}$ phosphate buffer.

Suction pressure method ${ }^{9}$ was also used for vascular sap extraction. The plates containing nutrient agar medium, Liao \& Chen medium, ${ }^{7}$ and sugarcane juice agar medium were inoculated with the prepared extracts using streak plate and spread plate methods.

Micro manipulator ${ }^{8}$ was also used for isolation of pure culture derived from a single R.S.D. bacterial cell.

\subsection{Pathogenicity test}

A suspension of a pure culture of R.S.D. bacterium was prepared in sterilized $0.01 \mathrm{M}$ phosphate buffer solution. Healthy sugarcane plants, $(4-\%$ months old) were inoculated with this suspension.

\subsection{Morphological and biochemical characters of the bacterium}

The bacterium was observed under the phase contrast microscope. Gram reaction, Acidfastness, Spore formation, (stained with malachite green) and motility of the bacterium were also examined with light microscope. ${ }^{4}$ 
The method developed by Davis et $\mathrm{al}^{2}$ was used to test hydrolysis of starch, esculin, and Tween. 80

Catalase production was tested by adding a drop of $3 \%$ Hydrogen Peroxide solution on to the colonies of the bacterium growing on an agar medium. 4

Oxidase production was determined by the Kovacs method. ${ }^{4}$

Cell division and generation time of the bacterium were also studied using micromanipulator.

\subsection{Survival of the bacterium on an inneret glass surface.}

Glass needles prepared from soda glass pasteur pipette tubings $(5 \mathrm{~mm}$ in diameter) were inserted separately in boiling tubes with the aid of the cotton wool plugs. These sets were sterilized by autoclaving at $120^{\circ} \mathrm{C}$ for $20 \mathrm{~min}$. Sterilized glass needles were contaminated with the bacterium and inserted again in the tubes. Viability of the bacterium was then checked daily by streaking each needle on fresh agar medium followed by incubation at $30^{\circ} \mathrm{C}$.

\subsection{Effect of temperature on viability of the bacterium}

The viability of the bacterium were checked using the actively growing bacterial colonies and bacterial cell suspension in $0.01 \mathrm{M}$ phosphate buffer solution.

The agar plates consisting of five days old growing bacterial colonies were incubated at following temperature, time combinations in an incubator.

At $50^{\circ} \mathrm{C}$ for $0.5,1.5,2.0,2.5,3.0 \mathrm{hr}$ respectively and at $56^{\circ} \mathrm{C}$ for the same time durations.

At the end of the incubation time the bacteria were subcultured in to fresh agar plates and then incubated at $30^{\circ} \mathrm{C}$ for $5-7$ days.

A similar study was carried out by using a bacterial suspension in sterile 0.01 M phosphate buffer. The McCartney bottles filled with the bacterial suspension were kept in the water bath at different temperature, time combination as above. The experiment was replicated four times.

\subsection{Sensitivity to the disinfectants}

The isolated bacterium was tested for its sensitivity to various concentrations of two phenolic disinfectants "Lysol" and "Phenol". The concentrations 
were $4 \%, 8 \%, 12 \%, 16 \%, 20 \%, 24 \%, 28 \%, 32 \%$ and $36 \%$.

A bacterial colony was picked up from agar plates using a sterilized standard inoculating loop (size $0.36 \mathrm{~mm}$ diameter) and was dipped in disinfectant solution for five seconds and streaked on sterilized agar plates after draining off the excess disinfectant.

This procedure was repeated for both disinfectants at the above concentrations. The experiment was replicated twice. The inoculated plates were incubated at $30^{\circ} \mathrm{C}$ for $5-7$ days.

The inhibitory concentration of each disinfectant were determined by observing the colony formation on agar plates (i.e. no colony formation of bacteria takes place at inhibitory concentrations).

\section{Results and Discussion}

The Ratoon Stunting Disease survey shows that the disease incidence in hot water treated primary nursery is $25 \%$ while that in hot water treated secondary nursery is $33 \%$. Untreated commercial sugarcane plantation shows a record of about $80 \%$ disease incidence. ${ }^{5}$ The percentage of disease incidence shows large variations from block to block in the sample fields (Table 1):

Table. 1. Percentage incidence of Ratoon Stunting Disease in hot water treated primary and secondary nurseries.

\begin{tabular}{|c|c|c|c|c|c|c|}
\hline \multirow[t]{3}{*}{ Block No. } & \multicolumn{2}{|c|}{ No. of samples tested } & \multicolumn{2}{|c|}{ R.S.D. positive } & \multicolumn{2}{|c|}{ Percentage incidence } \\
\hline & $\mathrm{I}^{\mathrm{ry}}$ & II $^{\mathrm{ry}}$ & $\mathrm{I}^{\mathrm{ry}}$ & $\mathrm{II}^{\mathrm{ry}}$ & $\mathrm{I}^{\mathrm{ry}}$ & II ry \\
\hline & Nursery & Nursery & Nursery & Nursery & Nursery & Nursery \\
\hline I & 64 & 360 & 15 & 65 & 23 & 18 \\
\hline II & 12 & 180 & 04 & 90 & 33 & 50 \\
\hline III & 40 & 330 & 08 & 124 & 20 & 37 \\
\hline IV & 76 & 150 & 21 & 60 & 27 & 40 \\
\hline & 192 & 1020 & 48 & 339 & 25 & 33 \\
\hline
\end{tabular}


This difference may be due to shortcomings in the treatment such as a drop in temperature, or shortening of the duration of heat treatment or it may also be due to the low heat penetration through thicker seed setts. Poor crop sanitation during the harvesting of the primary nursery may be a further contributing factor.

The samples obtained from Kantale, Moneragala and Pelwatte commercial sugarcane plantations were observed for the bacterium by using phase contrast microscope.

The results indicated that all the samples were contaminated with R.S.D. bacterium. Furthermore this investigation showed that the positive samples of bioassay were always associated with the coryneform bacterium. However some negative samples of bioassay also consisted of coryneform bacterium (Table 2).

Table 2. The comparison of Ratoon Stunting Disease and first ground nursery samples, their relationship in bio assay and phase contrast microsocope.

\begin{tabular}{llll}
\hline Site & $\begin{array}{l}\text { No. of } \\
\text { Samples }\end{array}$ & $\begin{array}{l}\text { Bio assay } \\
\text { technique } \\
\text { Positive Negative }\end{array}$ & $\begin{array}{l}\text { Phase contrast } \\
\text { microscope } \\
\text { Positive Negative }\end{array}$ \\
\hline
\end{tabular}

Commercial samples

$\begin{array}{lrrrrr}\text { Kantale } & 16 & 14 & 2 & 16 & 0 \\ \text { Monaragala } & 8 & 6 & 2 & 8 & 0 \\ \text { Pelwatte } & 8 & 0 & 8 & 8 & 0\end{array}$

1st ground nursery samples

Kantale : 8

0

8

0

8

Therefore, it is probable that the actual R.S.D. incidence in the surveyed area could be much higher than the values obtained from bioassay technique.

The experiment carried out to estimate the effect of the R.S.D. on cane yield, showed that there was a significant difference (at $\mathbf{P}=0.01$ ) in cane yield between inoculated and R.S.D. free control plants. The calculated cane yield for R.S.D. free crop was $135.65 \mathrm{MT} /$ ha. and for R.S.D. infected crop was $121.53 \mathrm{MT} / \mathrm{ha}$. A significant yield reduction was observed in ten plots out of fourteen replicates. The results of the experiment showed that there was no significant difference (at $\mathrm{P}=0.01$ and 0.05 ) in height and girth of stalks between control and treated plants. 
However, it was observed that the R.S.D. infection affected the stalk population by reducing the germination and tillering.

Table 3. The effect of Ratoon Stunting Disease on yield by reduction of both seedcane germination and tillering.

\begin{tabular}{|c|c|c|c|c|c|c|}
\hline \multirow[t]{2}{*}{ Repli. } & \multicolumn{2}{|c|}{ Germination counts } & \multicolumn{2}{|c|}{ Percentage germination } & \multicolumn{2}{|c|}{ Tillers per plot } \\
\hline & Treat. & Control & Treat. & Control & Treat. & Control \\
\hline 1 & 183 & 207 & 50.83 & 57.50 & 364 & 402 \\
\hline 2 & 169 & 159 & 46.94 & 44.17 & 333 & 378 \\
\hline 3 & 155 & 147 & 43.08 & 40.83 & 339 & 338 \\
\hline 4 & 123 & 156 & 34.17 & 43.33 & 276 & 359 \\
\hline 5 & 122 & 288 & 33.89 & 80.00 & 297 & 490 \\
\hline 6 & 187 & 325 & 51.94 & 90.28 & 247 & 405 \\
\hline 7 & 101 & 241 & 28.00 & 66.94 & 155 & 263 \\
\hline 8 & 165 & 185 & 45.83 & 51.39 & 366 & 415 \\
\hline 9 & 147 & 210 & 40.85 & 58.33 & 344 & 420 \\
\hline 10 & 154 & 174 & 42.78 & 48.33 & 342 & 387 \\
\hline 11 & 109 & 158 & 30.28 & 43.89 & 246 & 338 \\
\hline 12 & 123 & 253 & 34.17 & 70.28 & 269 & 332 \\
\hline 13 & 159 & 209 & 44.17 & 58.06 & 199 & 281 \\
\hline 14 & 103 & 195 & 28.61 & 54.17 & 137 & 252 \\
\hline Mean & 142.85 & 207.64 & 39.68 & 57.67 & 279.57 & 361.42 \\
\hline S.D & 29.08 & 52.90 & 8.08 & 14.69 & 75.43 & 66.45 \\
\hline
\end{tabular}

The investigation also showed that the causal bacterium did not effect on the juice quality and vascular anatomy of the plants.

When compared with healthy plants there was no marked difference in the overall fibre content or the fibre content in the top, middle and bottom regions. This indirectly shows that the R.S.D. does not damage vascular anatomy during the growth period. The direct microscopic observations on the diseased plant stem tissues also confirmed that the R.S.D. bacterium does not physically damage the xylem elements where the bacterium is colonized. The average number of vascular bundles per cross section of a sugarcane stem are about $1200^{5}$. But it was observed that less. than $1 \%$ of the vascular bundles were blocked by R.S.D. infection.

Therefore it is unreasonable to believe that the disease can decrease the water translocation in the plant to any extent which can create wilting in the plant. The isolation of R.S.D. causal bacterium was a critical stage of this experiment. Of the three methods employed for isolation the micromanipulator technique was the most reliable and quick. . 
Table 4.: The effect of Ratoon Stunting Disease (R.S.D.) on fibre content and juice quality in both R.S.D. inoculated (treated) samples and disease free (control) samples.

\begin{tabular}{llll}
\hline & & $\begin{array}{l}\text { Treated } \\
\text { (inoculated) }\end{array}$ & $\begin{array}{l}\text { Control } \\
\text { (Disease free) }\end{array}$ \\
\hline Fibre & Top & 11.59 & 11.75 \\
& Middle & 12.73 & 13.08 \\
Brix & Bottom & 14.13 & 14.15 \\
Pol \% & & 16.26 & 16.50 \\
Purity & & 13.78 & 13.90 \\
C.C.S & 84.21 & 83.98 \\
\hline
\end{tabular}

- C.C.S. (Commercial cane Sugar) - That percentage by weight of a quantity of cane which would be recovered as pure sucrose if milling and refining operations were conducted at a prescribed standard of efficiency.

The isolated bacterium was able to grow only in a complex medium consisting of L-Asparagine, Glutamic acid, Beef infusion, Casamino acid, Haemoglobin and essential minerals. The bacterial colonies which appeared on the agar medium were circular with entire margins, convex, glistering butyrus, and were white in colour with a maximum diameter of $0.5 \mathrm{~mm}$.

The isolated bacterium was gram positive, non-acid fast, nonendosporeforming, non-motile, pleomorpic rods. The bacterium did not hydrolyse starch, esculin, or Tween 80 and also were catalase positive and oxidase negative. These morphological and biochemical characters were similar to that recorded in previous investigations 2,7 for Clavibacter $x y l i$.

The cell division of the isolated bacterium was observed under the phase contrast microscope. The studies indicated that the cells divided by binary fission and was usually followed by a snapping movement. This is a characteristic feature in coryneform bacteria. As a result of a snapping movement the two cells were arranged in " $V$ " shape. The coccoid cells of the bacterium elongate first to form rods and then divide by binary fission. The time taken for a single division was four to five hours.

The contaminant bacterium survived for a long period on implements. The results of this investigation indicated that the organism can survive on glass surfaces without a supply of nutrients up to about 19 days. As the bacterium is a non-spore former the lethal temperature cannot be very high. However the bacterium survived at $50^{\circ} \mathrm{C}$ for three hours. Actively 
growing cells survived for one hour at $56^{\circ} \mathrm{C}$ in agar medium. The lethal temperature, time combination for the bacterium appeared to be $56^{\circ} \mathrm{C}$ for $1 \frac{1}{2} \mathrm{hr}$.

These results clearly indicated that the hot water treatment of seed cane setts at $50^{\circ} \mathrm{C}$ for three hours is not effective against R.S.D. control.

This bacterium was resistant to phenolic disinfectants which are usually employed to sterilize cane knives. The bacterium tolerated lysol concentration up to $24 \%$ and phenol concentration up to $28 \%$. During the seedcane harvesting, the cane knives are just dipped in disinfectant solution for sterilization. The normal disinfectant used for cane knives sterilization is lysol at $20 \%$ concentration. Such sterilization practices are not effective against R.S.D. control. The cane knives can be sterilized by dipping in $30 \%$ 'Lysol' or 'Phenol'. It has also been suggested that the bacterium can be transmitted from one plant to another via the cane knives used for seed cane harvesting.

\section{References}

1. DAVIS, M.J., GILlASPIE, A.G., HARRIS, R.W. \& LAWSON, R.H. (1980) Isolation of the causal bacterium. Science, $210: 1365-1367$.

2. DAVIS, M.J., GILlASPIE, A.G., VIDAVER, A.K. \& HARRIS, R.W. (1984) Clavibacter; Int. J. Systematic Bacteriology, 34 : 107-117.

3.' GILlASPIE, A.G., DAVIS, R.E. \& WORLEY,-F. (1973) Plant Disease Reporter, $57: 980-987$.

4. HARRIGAN, W.F. \& MCCANCE, M.E. (1966) Laboratory methods in Microbiology: 7-65, London NW 1 : Academic Press Inc. (London) Ltd.

5. HUTCHINSON, P.B. (1980) Control of Sugarcane Diseases in Sri Lanka, 27-35 : Dalgety, NSW., Waterford.

6. KING, N.J., MUNGOMERY, R.W., HUGES, C.G. (1953) Manual of Cane Growing, 2nd Ed : 9-11 : Sydney, London and Melbourne : Angus \& Robertson Ltd.

7. LIAO, C.H. \& CHEN, T.A. (1981) The Am. Phytopatbological Soc. 71 : $1303-1305$.

8. SKERMAN, V.D.B. (1982) Skerman Micromanipulator and Microforage. Brisbane University of Queensland. Dept. of Microbiology. 
9. STEINDL, D.R.L. (1960) Ratoon Stunting Disease : J.P. Martin, E.V. ABBOTT \& C.G. HUGHES : Sugarcane disease of the world: Vol I : 433-460 : Amsterdam, London, New York and Princeton: Elsevier Publishing Co.

10. STEINDL, D.R.L. (1976) Proc. of the Queensland Soc. of Sugarcane. Technologists. 43rd Conference: 71-72, Brisbane, Queensland.

11. STEINDL, D.R.L., TEAKLE, D.S. (1974) Proc. of Queensland Soc. of Sugarcane, 43 rd Conference : 101-104, Brisbane, Queensland.

12. STEINDL, D.R.L., TEAKLE, D.S. (1943) Laboratory Manual for Queensland Sugarmills. 5th Ed: 94-144 : Division of Mill Technology, Brisbane, Queensland. 